\title{
INTESTINAL HELMINTHIASES IN ECUADOR: THE RELATIONSHIP BETWEEN PREVALENCE, GENETIC, AND SOCIOECONOMIC FACTORS
}

\author{
Philip J. Cooper, Angel Guevara E. and Ronald H. Guderian
}

\begin{abstract}
Prevalence of infection with the intestinal helminths, Ascaris lumbricoides, Trichuris trichiura, Ancylostoma duodenale and Strongyloides stercoralis was examined in 632 residents of communities in Esmeraldas province of Ecuador. These communities were divided into two groups according to area of habitation which reflected different socioeconomic circumstances. Attempts were made to correlate infection status with race and $A B O$ blood group phenotype. The racial groups included blacks, Chachi amerindians, and mixed-race mestizos. Greater prevalences of infection were seen in the area of lower socioeconomic status. No racial or blood group associations with helminth infection were seen controlling for socioeconomic status.
\end{abstract}

Key-words: Helminth parasites. Race. ABO blood group phenotypes. Socioeconomic status.

Gastrointestinal helminthiases are an important cause of morbidity worldwide and affect a large proportion of mankind ${ }^{3}$. The factors that control susceptibility to geohelminthiases in man are poorly understood but include host behaviour, immunity, genetics, and nutrition.

The evidence for a role for genetic factors in determining susceptibility to intestinal helminth infections is largely epidemiological. For example, there is some evidence of a familial predisposition to high or low worm burdens ${ }^{6}$. Genetic associations with infection status may be examined at the population level using simple genetic markers such as race and blood group.

Racial differences in the prevalence, and the course and outcome of disease have been documented in infections with hookworm ${ }^{13}$, pinworm $^{5}$, onchocerciasis ${ }^{15}$, and leishmaniasis ${ }^{14}$. Many such studies suffer from the disadvantages of comparing populations from different geographical regions, making it impossible to control for confounding factors such as level of exposure and nutritional status.

There has been renewed interest in the role of the $\mathrm{ABO}$ blood group system in determining susceptibility to parasitic and bacterial infections.

\footnotetext{
National Centre for Tropical Diseases - extension Quito, Hospital Vozandes, Quito, Ecuador.

Address to: Dr. Philip Cooper. Hospital Vozandes, Casilla 1717-691, Quito, Ecuador.

Recebido para publicação em 01/03/93.
}

Individual $\mathrm{ABO}$ phenotypes have been associated with susceptibility to lymphatic filariasis ${ }^{11}$, giardiasis $^{1}$, cholera $^{4}$, and malaria ${ }^{12}$.

An opportunity to study the relative importance of genetic and socioeconomic factors in intestinal helminthiases exists in the Santiago river basin of Esmeraldas province in Ecuador. Here, three racial groups inhabit a rain forest area in close proximity to each other; indigenous Chachi amerindians, blacks (of African descent), and mixed-race mestizos. Racial differences in disease prevalence between Chachilla and blacks have already been reported in malaria ${ }^{10}$, yaws $^{8}$, and onchocerciasis ${ }^{7}$.

This study was performed to investigate the importance of genetics, using the markers of race and blood group, and socioeconomic status in determining the prevalence of intestinal helminthiases in the Santiago river basin.

\section{MATERIAL AND METHODS}

\section{Study area and population}

The province of Esmeraldas (latitude 1'96 S to $1^{\prime} 43 \mathrm{~W}$ and longitude $78^{\prime} 48 \mathrm{~W}$ to $80^{\prime} 9 \mathrm{~W}$ ) is the northwestern coastal province of Ecuador. This region where the elevation ranges approximately 0 200 metres, occupies $14,710 \mathrm{~km}$ and has a population of 285,600 (1982 census).

The Santiago river basin is composed of several large rivers and their tributaries in the northern 
Cooper PJ, Guevara AE, Guderian RH. Intestinal helminthiases in Ecuador: the relationship between prevalence, genetic, and socioeconomic factors. Revista da Sociedade Brasileira de Medicina Tropical 26:175-180, jul-set, 1993.

coastal part of the province, municipal of Eloy Alfaro. The area is primarily equatorial rain forest.

The study was conducted in communities living in this area. These communities include; indigenous amerindians, the Chachilla; blacks (of african descent); and mestizos of mixed european, indian, and african ancestry. Most families in this region are engaged in agriculture, logging, or fishing. The ethnographic features of these communities have been described elsewhere?.

The study area included Borbon (the principal town at the confluence of the rivers that form the Santiago River Basin) and rural villages which were accessible by either river or dirt road. The study area was divided into two: Area 1 (higher socioeconomic status) was Borbon and area 2 (lower socioeconomic status) included a total of 56 villages. Inhabitants of Borbon were wealthier than those from area 2 and had access to education and health facilities. Most households in Borbon had rudimentary sanitary facilities, electricity, and access to clean water. These were absent in area 2.

\section{Sample collection and analysis}

A single blood sample and stool sample were obtained from individuals in the study communities. To obtain and analyse these samples laboratories were set up at health centres in Borbon for area 1 and Zapallo Grande for area 2. A total of 296 were selected in area 1 and 336 in area 2 . A field team spent a total of 3 weeks in area 1 followed by 3 weeks in area 2 collecting and analysis samples. In Borbon, members of the community were encouraged to attend the health centre where samples were taken and examined immediately. In area 2, the team visited the villages by canoe and brought back approximately $\mathbf{5 0}$ volunteers daily (selected randomly) to Zapallo Grande where samples were taken and examined fresh. A data sheet was filled in for each patient which included information on age, sex, race, and address.

Stool suspensions were examined in saline and lugol's iodine by direct microscopy using low and high power. Three smears (each for saline and iodine) were examined from each individual for the presence of eggs or larvae of intestinal helminths. The direct method of stool examination was used as the formalin-ether concentration method ${ }^{15}$ offers little advantage in sensitivity over this method in areas of high helminth prevalence (Guevara, unpublished data).

Only infection with the 4 commonly found intestinal helminths were reported in this study. These were Ascaris lumbricoides, Trichuris trichiura, hookworm, and Strongyloides stercoralis. The hookworm species identified in this study according to egg size was Ancylostoma duodenale. This is the dominant species found along the west coast of South America ${ }^{2}$. All individuals infected with intestinal helminths were offered appropriate antihelminthic treatment.

Blood samples were obtained by venepuncture of antecubital veins using sterile vacutainer (Becton Dickinson, New Jersey, USA) sets. Red cells were tested for $\mathrm{ABO}$ blood group antigens using the test tube method.

\section{Consent}

Ethical consent for this study was obtained by consultation of community leaders and the Chachi Federation and also from the Ethical Committee, Hospital Vozandes, Quito.

\section{Statistical analysis}

Statistical analysis was performed using Minitab statistics programme on an Apple-Macintosh computer. Individuals with missing data were excluded from the analysis. Statistical associations were measured using Pearson's Chi-square. Statistical significance was taken as a probability of less than 0.05 .

\section{RESULTS}

\section{Population characteristics}

A total of 632 participants were included in the analysis. These comprised $398(63.8 \%)$ blacks, 67 (10.6\%) mestizos, and $167(26.4 \%)$ Chachilla. The study population was composed of 314 (49.7\%) males and $318(50.3 \%)$ females. The age range was 4-88 years. 
Cooper PJ, Guevara AE, Guderian RH. Intestinal helminthiases in Ecuador: the relationship between prevalence, genetic, and socioeconomic factors. Revista da Sociedade Brasileira de Medicina Tropical 26:175-180, jul-set, 1993.

\section{Population distribution}

There was a skew in the racial distribution of the study population between the two study areas. Most blacks lived in area $1(60.3 \%)$ and the mestizos (68.7\%) and Chachilla (79.0\%) lived mainly in area 2 .

\section{Blood group phenotypes}

This is best examined according to race. The distribution of blood group phenotypes was similar between blacks and mestizos with $70.6 \%$ and $62.7 \%$ respectively being blood group $O, 14.6 \%$ and $19.4 \%$ group $A, 13.1 \%$ and $14.9 \%$ group $B$, and $1.8 \%$ and $3.0 \%$ group $A B$. Almost all the Chachilla (98.8\%) were blood group $O$ with only $2(1.2 \%)$ being group $\mathrm{B}$. There were no Chachilla with groups $\mathrm{A}$ or $\mathrm{AB}$.

\section{Helminth prevalence}

A total of 480 (75.9\%) of the study population were infected with at least one helminth species. Infection rates for individual helminth species were as follows; $A$. lumbricoides 368 (58.2\%) infected, T. trichiura $320(50.6 \%)$, A. duodenale 158 (25.0\%), and S. stercoralis 37 (5.9\%).

\section{Race and helminth prevalence}

Prevalence rates tended to be higher in mestizos and Chachilla than in blacks (Table 1). This was true of combined infection $\left(\mathrm{x}^{2}=11.5 \mathrm{df}=2\right.$, $\mathrm{p}<0.01)$ and infection with $A$. lumbricoides $\left(\mathrm{x}^{2}=9.1\right.$ $\mathrm{df}=2, \mathrm{p}<0.05)$ and $A$. duodenale $\left(\mathrm{x}^{2}=21.3 \mathrm{df}=2\right.$, $p<0.001)$. These racial differences were not statistically significant in infections with $T$. trichiura. In the case of $S$. stercoralis, prevalences were too low to detect any differences.

\section{Blood group and helminth prevalence}

Blood group associations were seen in infection with $A$. duodenale. Groups $\mathrm{O}$ and $\mathrm{AB}$ were seen more commonly in infected individuals $\left(x^{2}=9.7\right.$ $\mathrm{df}=3, \mathrm{p}<0.05$ ). Infection rates with this parasite according to blood group are shown in Table 2. Only 9 individuals were group AB.

\section{Area and helminth prevalence}

Prevalence rates were higher in area 2 than area 1 (Table 1). This was true of combined infection $\left(\mathrm{x}^{2}=66.8 \mathrm{df}=1, \mathrm{p}<0.001\right), A$. lumbricoides $\left(\mathrm{x}^{2}=7.0 \mathrm{df}=1, \mathrm{p}<0.01\right)$, T. trichiura $\left(\mathrm{x}^{2}=25.8\right.$ $\mathrm{df}=1, \mathrm{p}<0.001)$, and A. duodenale $\left(\mathrm{x}^{2}=21.3\right.$ $\mathrm{df}=1, \mathrm{p}<0.001)$. S. stercoralis was more prevalent in area 1 (not significant).

\section{Area, race, and helminth prevalence}

Analysis of helminth prevalence by race in the two areas showed markedly higher prevalences in all races in area 2 (Table 1). These differences were not statistically significant in infections with $A$. lumbricoides. S. stercoralis was more prevalent in area 1 in blacks and mestizos (not significant).

There were no inter-racial differences in helminth prevalence in neither area 1 nor area 2 (Table 1). This was true for combined and individual helminth infections.

\section{Area, blood group, and helminth prevalence}

The blood group $\mathrm{O}$ and $\mathrm{AB}$ associations with $A$. duodenale infection were confounded by area. If the prevalence of $A$. duodenale infection is examined according to blood group in areas 1 and 2, the associations disappear (Table 2). The finding of $100 \%$ prevalence in individuals with group $A B$ in area 2 is difficult to interpret as only 2 individuals had this blood group.

\section{DISCUSSION}

Area of habitation was the major factor determining helminth prevalence. Infection rates for most helminths were higher in area 2 than area 1 . These findings were very strongly statistically significant. Gut helminth transmission is likely to be greater in area 2 as this area is characterised by poor access to health care and education, and by the absence of clean water and sanitation and the irregular use of footwear. The study participants were and sanitation and the irregular use of footwear. The study participants were not questioned about antiparasitic medication which might account for some reduced prevalence in area 1 due to better 
Cooper PJ, Guevara AE, Guderian RH. Intestinal helminthiases in Ecuador: the relationship between prevalence, genetic, and socioeconomic factors. Revista da Sociedade Brasileira de Medicina Tropical 26:175-180, jul-set, 1993.

Table 1 - Helminth infection prevalence according to racial group and area of habitation.

\begin{tabular}{lcclllll}
\hline Race & Area & Number & Combined & Al & Tt & Ad & Ss \\
\hline All groups & & & & & & & \\
& 1 & 296 & 61.2 & 52.7 & 39.9 & 8.8 & 7.1 \\
& 2 & 336 & $89.4 * * *$ & $63.1 * *$ & $60.1 * * *$ & $39.3 * * *$ & 4.8 \\
& $\mathrm{~T}$ & 632 & 76.0 & 58.2 & 50.6 & 25.0 & 5.9 \\
Blacks & & & & & & & \\
& 1 & 240 & 60.8 & 50.8 & 40.8 & 8.3 & 6.3 \\
& 2 & 158 & $88.0 * * *$ & 58.2 & $59.5 * * *$ & $36.1 * * *$ & 2.5 \\
& $\mathrm{~T}$ & 398 & 71.6 & 53.8 & 48.2 & 19.4 & 4.8 \\
Mestizos & & & & & & & \\
& 1 & 21 & 57.1 & 57.1 & 28.6 & 4.8 & 19.1 \\
& 2 & 46 & $91.3 * *$ & 73.9 & $60.9 *$ & $37.0 * *$ & 8.7 \\
& $\mathrm{~T}$ & 67 & 80.6 & 68.7 & 50.8 & 26.9 & 11.9 \\
Chachis & & & & & & & \\
& 1 & 35 & 65.7 & 62.9 & 40.0 & 14.3 & 5.7 \\
& 2 & 132 & $89.4 * * *$ & 65.2 & $60.6 *$ & $44.0 * *$ & 6.1 \\
& $\mathrm{~T}$ & 167 & 84.4 & 64.7 & 56.3 & 37.7 & 6.0 \\
\hline
\end{tabular}

$\mathrm{T}=$ total; Combined $=$ all 4 helmints; $\mathrm{Al}=A$. lumbricoides $; \mathrm{Tl}=T$. trichiura; $\mathrm{Ad}=A$. duodenale $; \mathrm{Ss}=S$. stercoralis

Test statistic of comparison of prevalences between areas 1 and 2 are shown

(1 degree of freedom): * $p<0.05^{* *} p<0.01^{* * *} p<0.001$

Table 2 - Prevalence of $\mathrm{A}$. duodenale infection according to blood group and area.

\begin{tabular}{|c|c|c|c|c|c|c|}
\hline \multirow[t]{2}{*}{ Blood group } & \multicolumn{2}{|c|}{ Both areas } & \multicolumn{2}{|c|}{ Both areas } & \multicolumn{2}{|c|}{ Both areas } \\
\hline & $n^{0}$ & $\%$ & $n^{0}$ & $\%$ & $n^{0}$ & $\%$ \\
\hline o & $135 / 488$ & 27.7 & $17 / 198$ & 8.6 & $118 / 290$ & 40.7 \\
\hline A & $11 . / 71$ & 15.5 & $5 . / 44$ & 11.4 & $6 . / 27$ & 22.2 \\
\hline B & $9 . / 64$ & 14.1 & $3 . / 47$ & 6.4 & 6.117 & 35.3 \\
\hline$A B$ & 3.19 & 33.3 & 1.17 & 14.3 & $2 . / 2$ & 100.0 \\
\hline Total & $158 / 632$ & 25.5 & $26 / 296$ & 8.8 & $132 / 336$ & 39.3 \\
\hline
\end{tabular}

access to health facilities.

Populations surveys have provided empirical data relating to racial differences in prevalence of a number of helminths ${ }^{571315}$. Racial differences in disease prevalence has often been cited as evidence for genetic control of susceptibility. Interpretation of such data is complicated by the many environmental differences that may influence these such as level of exposure, nutrition, and intercurrent infection. In this study these factors were controlled as well as possible. In each area, the 3 racial groups shared the same environment and were of similar nutritional status and were likely to be exposed to similar levels of infection with gut helminths as well as other infectious diseases.

The apparent racial differences in helminth prevalence seen in this study were strongly confounded by area of habitation. For example, prevalence rates were higher in mestizos and Chacilla than in blacks for combined infection, $A$. lumbricoides, and $A$. duodenale. However, when analysed by area, all racial differences were lost.

A number of studies have looked for broad disease associations between disease prevalence and outcome and blood group phenotypes at the population level in parasitic infectious ${ }^{11}$. Our results showed possible associations of blood groups $\mathrm{O}$ and $\mathrm{AB}$ with infection with $A$. duodenale. It is 
Cooper PJ, Guevara AE, Guderian RH. Intestinal helminthiases in Ecuador: the relationship between prevalence, genetic, and socioeconomic factors. Revista da Sociedade Brasileira de Medicina Tropical 26:175-180, jul-set, 1993.

possible that the group $A B$ association is valid but numbers were too small to exclude an area effect. The group $O$ association was strongly confounded by area: The proportion of individuals with blood group $O$ was higher in all races in area 2 where $A$. duodenale prevalence was much higher. In addition, the Chachis, who lived predominantly in area 2, had the highest prevalence of $A$. duodenale and were almost exclusively group $O$.

This study illustrates the importance of controlling for socioeconomic circumstances in epidemiological investigations of geohelminthiases. Area of habitation was a good indicator of both socioeconomic factors and the level of geohelminth transmission and prevalence. If the study area had not been divided in to two to reflect these differences, a number of spurious associations between race and blood group and helminth prevalence would have been seen.

These findings do not preclude a role for genetics in susceptibility to gut helminths. The use of prevalence studies to detect racial and genetic determinants of infection status with helminths, though useful, may be of limited power in revealing such associations. The use of simple genetic markers such as race and blood group may be too crude to detect valid genetic associations. Alternatively, the very strong influence of environment demonstrated in this study may have masked weaker associations of race or blood group.

\section{RESUMO}

A prevalência de infecçzes com helmintos Ascaris lumbricoides, Trichuris trichiura, Ancylostoma duodenale e Strongyloides stercoralis foi examinada em 632 pessoas em diferentes comunidades na Região de Esmeraldas no Equador. Estas comunidades foram divididas em dois grupos conforme a área na qual residem, o que reflete diferentes circunstâncias sócioeconômicas. Intentou-se correlacionar os tiposde infecção com a raça e os grupos sanguíneos $A B O$. Nestes grupos raciais estão incluídos negros, amerindios Chachi, $e$ mestiços. Notou-se a prevalência de infecções nas áreas sócio-econômicasmais baixas. Não se encontrounenhumà relação com a infecção helmíntica e raça ou grupo sanguíneo depois de controlar-se o status sócioeconômico.

Palavras-chaves: Parasitos helmintos. Raça. Grupo sanguíneo ABO fenótipo. Status sócio-econômico.

\section{ACKNOWLEDGEMENTS}

We wish to thank Don Bundy for helpful comments on the manuscript and Tony Fulford for statistical advice. We also thank the inhabitants of the communities involved in this study for their cooperation.

\section{REFERENCES}

1. Barnes GL, Kay R. Blood groups and giardiasis. Lancet 1:808, 1977.

2. Brown HW, Neva FA. Basic Clinical Parasitology, 5th edition. Appleton-Century Crofts, Norwalk, Connecticut p.122-123, 1983.

3. Bundy DAP. Population ecology of intestinal helminth infections in human communities. Philosophical Transactions of the Royal Society of London 321:405-420, 1988.

4. Clemens JD, Sack DA, Harris JR, Chackraborty J, Khan MR, Huda S, Ahmed F, Gomes J, Rao MR, Svennerholm AM, Holmgren J. ABO blood group and cholera: new observations on specificity of risk and modification of vaccine efficacy. Journal of Infectious Diseases 159:770-773, 1989.

5. Cram EB. Studies on oxyuriasis. XXIV Comparative findings in the white and negro races. Proceedings of the Helminthological Society of Washington 7:31-35, 1940.

6. Forrester JE, Scott ME, Bundy DAP, Golden MHN. Predisposition of individuals and families in Mexico to heavy infection with Ascaris lumbricoides and Trichuris trichiura. Transactions of the Royal Society of Tropical Medicine and Hygiene 84:272-276, 1990.

7. Guderian RH, Beck BJ, Proano SJR, Mackenzie CD. Onchocerciasis in Ecuador, 1980-1986: Epidemiological evaluation of the disease in the Esmeraldas Province. European Journal of Epidemiology 5:294-302, 1989.

8. Guderian RH, Guzman JR, Calvopina M, Cooper PJ. Studies on a focus of yaws in the Santiago Basin, Province of Esmeraldas, Ecuador. Tropical and Geographical Medicine 43:142-147, 1991.

9. Guderian RH, Leon LA, Leon R, Corral F, Vasconez C, Johnston TS. Report on a focus of onchocerciasis of Esmeraldas province of Ecuador. The American Journal of Tropical Medicine and Hygiene 31:270274, 1982.

10. Guderian RH, Vargas GJ. Duffy blood group distribution and the incidence of malaria in Ecuador. Transactions of the Royal Society of Tropical 
Cooper PJ, Guevara AE, Guderian RH. Intestinal helminthiases in Ecuador: the relationship between prevalence, genetic, and socioeconomic factors. Revista da Sociedade Brasileira de Medicina Tropical 26:175-180, jul-set, 1993.

Medicine and Hygiene 80:162-163, 1985.

11. Higgins DA, Jenkins DJ, Partono F. Timorian filariasis and $\mathrm{ABO}$ blood groups. Transactions of the Royal Society of Tropical Medicine and Hygiene 79:537-538, 1985.

12. Hill AVS. Malaria resistance genes: a natural selection. Transactions of the Royal Society of Tropical Medicine and Hygiene 86:225-226, 1992.

13. Keller AE, Leathers WS, Knox JC. The present status of hookworm infestation in North Carolina. American Journal of Hygiene 26:437-454, 1937.

14. Walton BC, Valverde L. Racial differences in espundia. Annals of Tropical Medicine and Parasitology 73:23-29, 1979.

15. Woodruff AW, Choyce DP, Muci-Mendoza F, Hills M, Pettit LE. Onchocerciasis in Guatemale. A. Clinical and parasitological studies with comparasion between the disease there and in East Africa. Transactions of the Royal Society of Tropical Medicine and Hygiene 60:707-719, 1966.

16. World Health Organization. Basic laboratory methods in medical parasitology. World Health Organization, Geneva p.16-17, 1991. 